INFORMES

\title{
A bibliometric analysis of research on surrogacy: Current trends and gaps between international law and new technology
}

\author{
Un análisis bibliométrico de la investigación sobre la gestación subrogada: \\ Tendencias actuales y brechas entre el derecho internacional \\ $y$ las nuevas tecnologías
}

\author{
Waldimeiry Correa da Silva \\ Universidad de Sevilla, Spain
}

\begin{abstract}
Surrogacy or surrogate motherhood is a global phenomenon that has been on the rise since the 1980 s. Academic research on surrogacy has adapted to the emerging challenges of this practice by becoming vast and highly multidisciplinary. To orient future research, we employ a bibliometric analysis to make a radiograph of past and current trends in the surrogacy literature. Our results indicate that (1) despite surrogacy being a global market, perspectives from economics and international law are being neglected; (2) research is not addressing the most concerning issues for policy, such as exploitation or human trafficking and the impact of technologies for the protection of the rights of the parties involved; and (3) surrogacy literature output is largely clustered in a handful of Western countries. Taken together, these results point to a huge gap between research and policy. Future research should address these neglected issues to better inform policy makers and the impact of technology on the law.
\end{abstract}

KEYWORDS Surrogacy, human rights, reproductive tourism, bibliometric analysis, technology on the law.

RESUMEN La subrogación o gestación subrogada es un fenómeno global que ha crecido exponencialmente desde la década de los ochenta. La investigación académica sobre la gestación subrogada se ha adaptado a los desafíos emergentes de esta práctica y se ha vuelto amplia y multidisciplinar. Para orientar futuras investigaciones, empleamos un análisis bibliométrico para hacer un diagnóstico referente a las tendencias pasadas y actuales en la literatura académica de la gestación subrogada. Los resultados indican que: 1) a pesar de que la subrogación es un mercado global en expansión, se están descuidando las perspectivas del derecho internacional y de la economía; 2) la investigación 


\begin{abstract}
no está abordando los temas más preocupantes para las políticas, como la explotación o la trata de personas y el impacto de las tecnologías para la protección de derechos de las partes implicadas; y 3) la producción de conocimiento sobre la gestación subrogada se concentra en gran parte en algunos países occidentales. En conjunto, estos resultados apuntan a una enorme brecha entre la investigación y la política. Las investigaciones futuras deberían abordar estos temas desatendidos para informar mejor a los responsables políticos y el impacto de la tecnología en la ley.
\end{abstract}

PALABRAS CLAVE Subrogación, derechos humanos, turismo reproductivo, análisis bibliométrico, derecho y tecnología.

\title{
Introduction
}

Surrogacy was originally defined as "the practice whereby one woman carries a child for another with the intention that the child should be handed over after birth" (Warnock, 1985). Surrogacy agreements, both altruistic and commercial, were popularized in the 1980 s due to the development of in vitro fertilization (IVF) and other assisted reproductive technology (ART) procedures.

The advent of new reproductive technology and the consequential fertility industry have posed serious health and social challenges to policy makers, causing fierce controversy. Those in favor of the practice present arguments mostly based on reproductive rights (Macklin, 1988; Robertson, 1988), its benefits for both the intended parent(s) and the surrogate mother, and the autonomy of women over their bodies (Steinbock, 1988; Patel, 2018). On the other hand, those against surrogacy and its commercial dimension defend their position by stating that the practice violates fundamental rights of both the surrogate mother and the child, as consent may not be free (Farley, 2018; Mohapatra, 2012) and that it leads to the commodification and dehumanization of the child (Vitale, 2017; Dworkin, 1983).

The debate is still open, and the international community has not reached an agreement on the issue. In contrast, there is a disparity in legislative approaches to surrogacy. There are three main models of surrogacy legislation: altruistic surrogacy, commercial surrogacy or total prohibition. Differences in legislation "force" an increasing number of intended parents to travel abroad to find a surrogate mother. Therefore, reproductive tourism, which includes but is not limited to surrogacy, has progressively expanded as more countries legalize commercial surrogacy and other ART (Palattiyil, 2010). Currently, it is estimated that each year, more than 25,000 women travel abroad for reproductive tourism (Patel, 2018), which is also referred to as cross-border reproductive care (Pennings et al., 2008).

The transnational and globalized dimension of surrogacy raises grave concerns for the international community. Controversies over a child's affiliation and natio- 
nality may lead to statelessness. The movement of intended parents and surrogate mothers creates problems of human security (Rigon \& Chateau,2016; Emakunde, 2018) . In addition, the globalization of the fertility industry takes advantage of social inequalities within and among countries, raising mounting concerns about exploitation or even human trafficking (HCCH, 2015; Correa da Silva, 2021).

In conclusion, surrogacy is an increasingly relevant issue for the international community and policy makers but also a truly complex issue. It combines medical, ethical, legal, social, economic and international dimensions. For that reason, research on surrogacy is vast and multidisciplinary. To visualize the whole picture of surrogacy research, we perform a bibliometric analysis of the academic literature on surrogacy from 1954 to June 2020. This analysis allows us to discover temporal, geographical and thematic trends and to identify the gaps surrogacy research should address to better inform policy makers.

\section{Materials and Methods}

\section{Study design}

We employed a bibliometric analysis to accomplish the aims of our study. Bibliometrics consists of a quantitative analysis of scientific production data from the literature, such as scientific journal articles and books and their corresponding citation counts (Thomson Reuters, 2008). It provides a quantitative measure of the volume, temporal and geographical trends and scope of publications on surrogacy. Therefore, bibliometric analysis constitutes an essential tool to explore where when and how surrogacy has been studied in recent decades.

\section{Search strategy}

We performed a Boolean search of the Web of Science (WoS) complete collection for the period of 1954 to June 2020. WoS is a global citation search engine whose database stores "ideas across disciplines and time from over 1.7 billion cited references from over 159 million records" from leading academic, corporate, and government institutions over 115 years (Clarivate, 2020). Its complete collection includes general scientific databases, as well as specialized medicine databases, such as Medline. Given the multidisciplinary nature of our enquiry, the inclusion of all databases available in WoS was essential to correctly capture the current state of surrogacy research.

Table 1 presents our Boolean search strategy, namely, our keywords and exclusions. Keyword selection is of the utmost importance in bibliometric analyses because it determines the documents retrieved and, therefore, the results of the study. As surrogacy is still a highly debated issue, the terminology employed by surrogacy researchers is varied and often value laden. To gather as many unbiased and repre- 
Table 1. Boolean search strategy

\begin{tabular}{|c|c|}
\hline Keywords & Exclusions \\
\hline 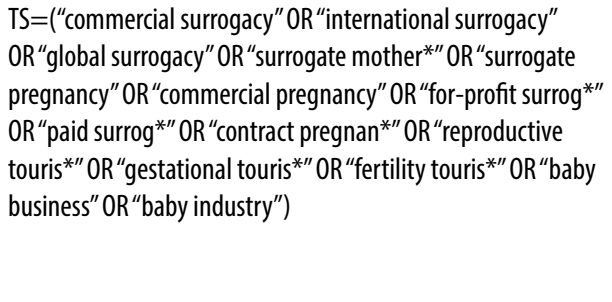 & 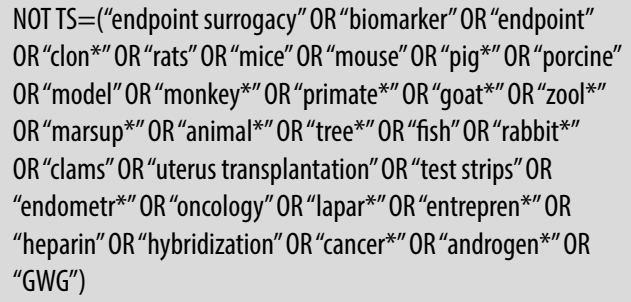 \\
\hline
\end{tabular}

Note: symbol * includes all possible grammatical endings.

sentative databases as possible, we employed neutral, favorable and critical keywords. These were selected from relevant previous literature (Beeson, Darnovsky, Lippman, 2015), the glossary published in 2014 by the Hague Conference on Private International Law (HCCH, 2014) and Convention on the Rights of the Child (UN/RES 44/25, 1989). We also analyzed other relevant international reports on the subject, such as the annual reports of the Human Rights Council, Special Rapporteur on the sale and sexual exploitation of children ${ }^{1}$.

The selected keywords are shown in the first column of Table 1. They were searched among the topic field tags in WoS, which include the titles, abstracts and descriptors of publications. We did not limit our inquiry to explicit surrogacy documents, as broader scope publications, such as those studying fertility tourism, usually include surrogacy as a relevant but not exclusive object of study (Virani, Wellstead \& Howlett, 2020). Finally, the second column of Table 1 presents the excluded keywords. These were chosen to minimize the number of false-positive results, such as those regarding surrogate pregnancy in animal models. We also excluded patent records from the Derwent Innovation Index. As a result of the Boolean search, we obtained a database comprised of 2,251 journal articles, books and conference proceedings.

\section{Bibliometric indicators}

Bibliometric indicators measure the volume and impact of knowledge production on a certain topic. The most useful and commonly employed metrics are the number of publications (volume) and citations (impact). These bibliometric indicators are then used to analyze the temporal trends and geographical distribution of global surrogacy research. We also present the most productive and influential journals. In line with

1. OHCHR. Special Rapporteur on the sale and sexual exploitation of children. Available at https:// bit.ly/3JtT 7 lr. 
past bibliometric analysis literature, we use a threshold of ten to display our results (Sweileh, 2018; Gonzalez, et al.; 2020]. In addition to those indicators, WoS categories show which research fields a publication belongs to. These data are analyzed and presented as the top ten most common and influential research areas to shed light on how surrogacy is being approached and which perspectives are lacking.

\section{Network and word analysis}

Bibliometric indicators are complemented with network linkages and word analysis. First, we explored international collaboration on surrogacy research, which is particularly useful for the study of such a highly globalized phenomenon. In addition, the terms and topics covered by the current literature are analyzed. We combined network maps and word analysis to uncover the main trends and subjects in surrogacy research, as well as its main gaps. For this analysis, we selected those words chosen by the authors to be in the title, abstract or keywords, which are the most relevant terms of the publications. These maps are created based on the co-occurrence-the appearance of two terms in the same publication-using VOSviewer software ${ }^{2}$.

\section{Results}

\section{Temporal trend}

As a result of our search, we retrieved 2,251 documents published from 1954 to June 2020. Only a dozen publications addressed surrogacy from 1977 , and they did so as a possible advancement of artificial reproductive technologies (ART). In 1978, the first person conceived in vitro was born, which provided academic debate and research with a starting place. In the following decade, third-party reproduction developed quickly, thereby widening the scope of the ethical and legal controversies doctors and policy makers faced.

In 1987, and 1988, the Baby $M$ case shocked public opinion in the US. media coverage and public debate on the case prompted a dramatic increase in academic production. Just in those two years, 287 documents were published. Figure 1 shows this historic high in surrogacy research. After that spurt of publications, interest the issue declined until the 2000 . From 2008 to 2019, the pace of publication on third-party reproduction increased again. Some of the most cited papers on surrogacy were published in those years, and concerns about outsourcing surrogacy contracts to developing countries began to mount. Publication growth has continued ever since and has reached annual numbers not seen since the Baby $M$ years.

2. VOSviewer is a software tool for constructing and visualizing bibliometric networks. For a more extensive discussion of the functionality of VOSviewer, available in https://www.vosviewer.com. 


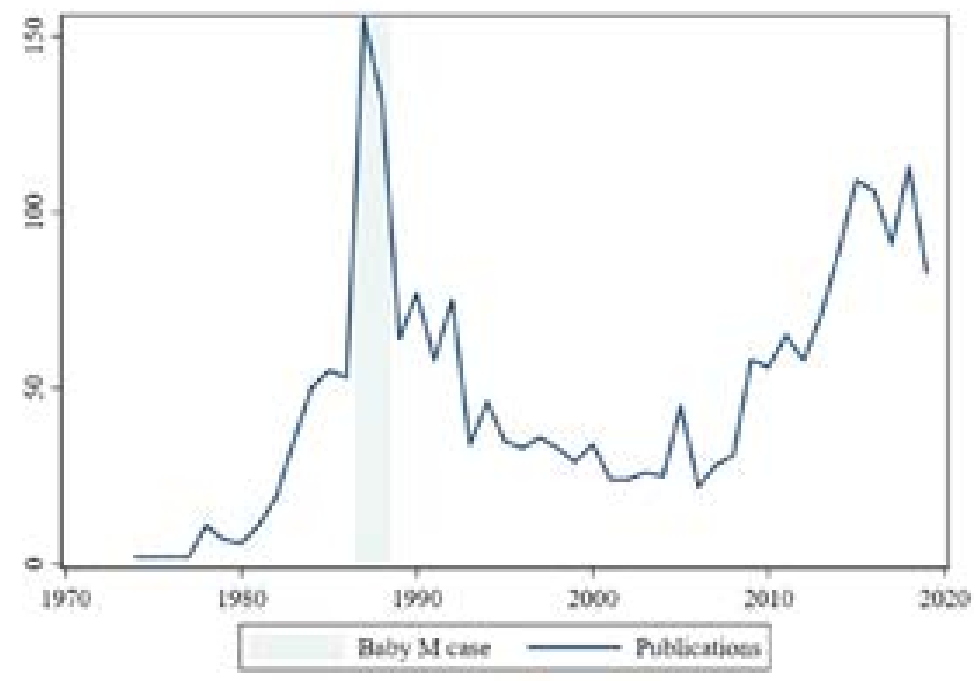

Figure 1. Publications on surrogacy per year, 1975-2019. Source: Own elaboration based on bibliometric analysis.

\section{Geographical distribution}

The production of research on surrogacy is geographically uneven. Figure 2 shows this imbalance in the number of publications by authors' country affiliation. The United States (989 publications), the United Kingdom (272) and Australia (99) comprise $63 \%$ of all documents on surrogacy. They lead not only to scientific production but also especially to its impact; their publications received $71 \%$ of the citations.

Other countries with a traditional feminist point of view, such as Canada, Spain or France, rank prominently in surrogacy research and debate. ${ }^{3}$ India and Israel, where different regulations have been enacted, figure as well among the top ten most productive countries in terms of surrogacy research. India has been a highly studied case in surrogacy research since commercial surrogacy was legalized in 2004. Nevertheless, the research on Indian surrogacy receives much less attention in regard to India ( 2.5 cites on average) than in the rest of the world (6.9 cites on average). This kind of colonial bias discourages local knowledge production and overrepresents Western discourse on a global issue such as surrogacy.

As a global phenomenon, international collaboration on surrogacy research is expected, if not assumed. However, only a shocking $4 \%$ of all retrieved documents have been produced by authors affiliated in different countries. The lack of collaboration of

3. Perhaps due to the existing relationship between the commodification of both women's bodies and that of the product of the commercial relationship, the baby that is generated thanks to new technologies. 


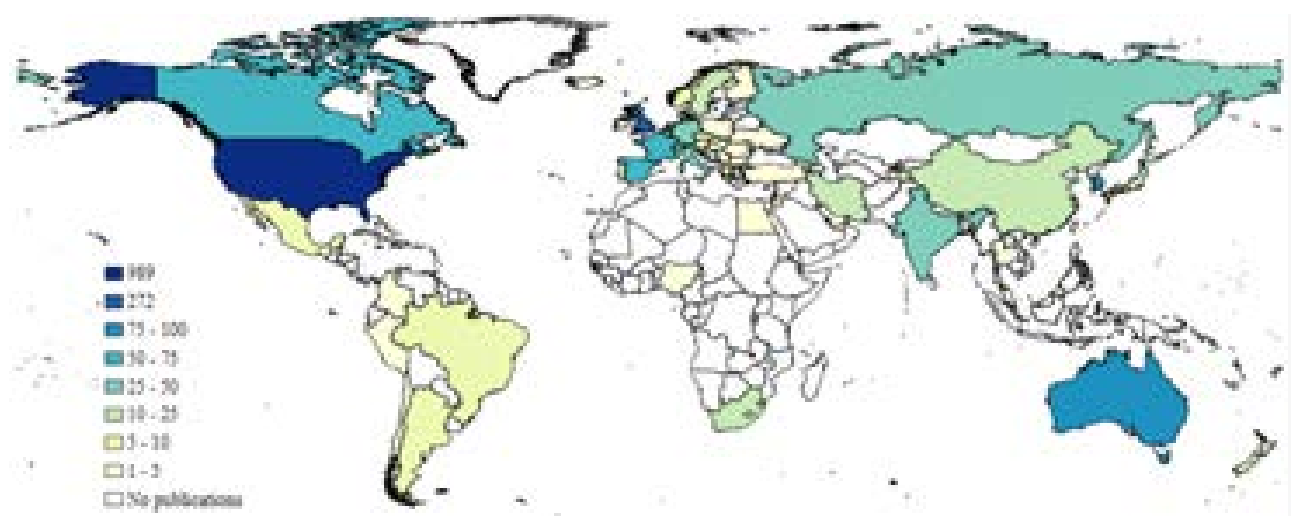

Figure 2. Total publications on surrogacy by author's country affiliation, 1954-2020. Source: own elaboration

international research networks is worrisome because such collaboration is needed to correctly grasp the transnational dimension of this increasingly global phenomenon.

\section{Research areas}

Figure 3 illustrates the top ten most common research areas from which surrogacy is approached. Sociology, obstetrics and gynecology, and government and law are the most popular areas, with more than $10 \%$ of all publications belonging to each of them. Except for sociology, these areas are some of the most influential. However, the "other topics in social sciences" group, which includes bioethical debates and the intersection of diverse fields in social sciences, has had the greatest impact, with an average of 9 cites per publication.

The relevant presence of medical, ethical, social and legal fields in surrogacy research was expected. Nonetheless, it is staggering that international relations and international law do not appear in the top ten. Surrogacy has a crucial transnational dimension, comprising medical and reproductive tourism, cross-border reproductive care, human rights, labor outsourcing and citizenship issues. Nevertheless, only $0.2 \%$ of all publications study surrogacy from an internationalist legal perspective. Moreover, the lack of economic research on the issue is shocking. Although commercial surrogacy is a global market as well as a billion-dollar industry, just $2.3 \%$ of all research uses an economic approach.

\section{Sources}

Which journals publish surrogacy research? Table 2 displays the top ten most active journals in its first column. They have varied scopes but are mainly biomedical, ethical and medical-legal journals. This variety illustrates the intrinsic interdisciplinarity 


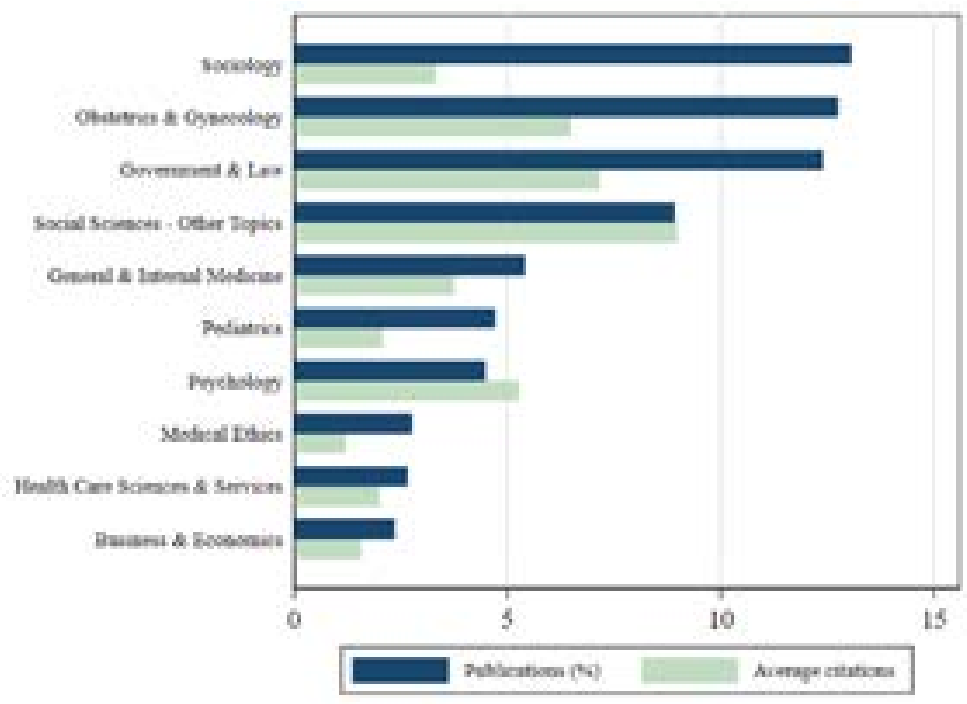

Figure 3. Top ten research areas in surrogacy literature. Source: Own elaboration based on bibliometric analysis

of surrogacy research. Reproductive Biomedicine Online, with 44 publications dedicated to surrogacy, is the most productive journal, followed by the Hastings Center Report and Bioethics. However, research is highly distributed across publication venues, as the top ten most active journals account for only $13.2 \%$ of all publications.

The top ten most influential journals are presented in the fourth column of Table 2. Reproductive Biomedicine Online, with 859 citations, leads the ranking again. In this case, some journals with fewer but high-impact publications figure on the list, such as Philosophy \& Public Affairs (6o citations per publication) or Signs (21). Again, biomedicine, ethics and law are the main research fields of these journals. The new development is the inclusion of feminism and gender studies (Signs) and tourism (Tourism Management) among the most influential journals' scopes.

\section{Word analysis}

To understand the thematic trends in surrogacy research, we performed a word analysis which examines which terms are the most used and how they are related to one another. First, we analyzed the more than 18,0oo unique terms appearing in the titles and abstracts. Figure 4 shows the 75 most relevant-most frequently occurring-terms in surrogacy research. There are separate and differentiated clusters. Legal approaches focus on terms such as contract, court, custody, and paternity, whereas others study the social dimension of the phenomenon: service, gender, reproductive tourism, cross-border reproductive care (CBRC), labor, etc. 
Table 2. Top ten most active and most influential journals on surrogacy research

\begin{tabular}{|lllll|}
\hline Rank & Most active journals & $\mathrm{N}^{1}$ & Most influential journals & Cites \\
\hline 1 & Reproductive Biomedicine Online & 44 & Reproductive Biomedicine Online & 859 \\
\hline 2 & Hastings Center Report & 33 & Journal of Medical Ethics & 360 \\
\hline 3 & Bioethics & 30 & Bioethics & 336 \\
\hline 4 & British Medical Journal & 28 & Human Reproduction & 309 \\
\hline 5 & Lancet & 25 & Philosophy \& Public Affairs & 241 \\
\hline 6 & Journal of Medical Ethics & 22 & Tourism Management & 240 \\
\hline 7 & Law, Medicine \& Health Care & 22 & Signs & 208 \\
\hline 8 & Journal of Law and Medicine & 21 & Wisconsin Law Review & 199 \\
\hline 9 & Medicine and Law & 21 & Annual Review of Anthropology & 189 \\
\hline 10 & Politics and the Life Sciences & 21 & Southern California Law Review & 176 \\
\hline
\end{tabular}

1. $N$ refers to number of publications

In addition to the most relevant terms, Figure 4 presents their temporal evolution. Legal studies about surrogacy, which appeared mainly around the Baby $M$ case, are giving way to novel approaches. Most actual terms are those related to gender studies and the transnational dimension of surrogacy: gender, transnational surrogacy, CBRC, reproductive/medical tourism, human rights, citizens, labor, and race. Therefore, we can conclude that surrogacy research is shifting from the legal-ethical debate to the study of the globalized, gendered, racialized dimensions of commercial surrogacy.

In addition to the words used for the titles and abstracts, author-selected keywords condense the scope of each publication. For that reason, we analyzed the keywords most often chosen by the authors of surrogacy research. Figure 5 displays the 75 most common keywords in surrogacy documents. As expected, surrogacy, surrogate motherhood and assisted reproduction were the most commonly used keywords, followed by reproductive tourism, medical tourism, cross-border reproductive care and ethics.

Some clusters of keywords appear in Figure 5. They reflect the concerns of each thematic approach. For example, the cluster composed of cross-border reproductive care, reproductive tourism and medical tourism, the keywords of those publications that study the transnational dimension of surrogacy, is strongly related to human 

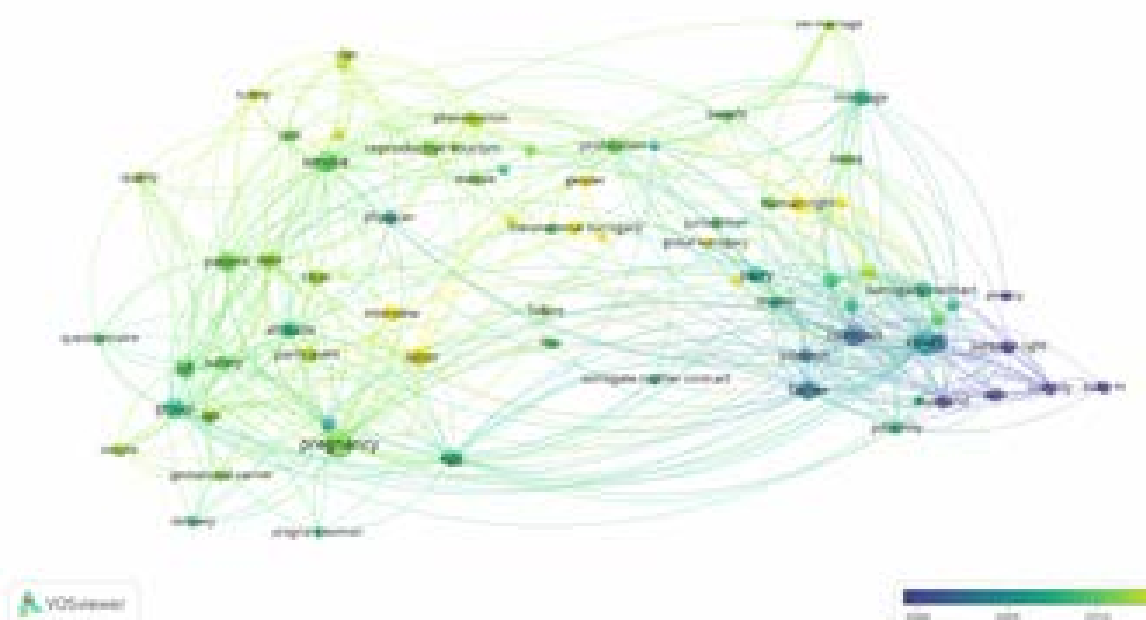

Figure 4. Co-occurrence network of most relevant terms in titles and abstracts of surrogacy studies. Note: Nodes depict terms, and their linkages convey co-occurrence relationships. Larger nodes indicate terms with more occurrences. Color shows average publication year for each term. Source: Own elaboration based on bibliometric analysis.

rights, ethics and legislation. On the other hand, we can observe the cluster of those studies concerned with commodification, exploitation, abortion, autonomy and gender.

Moreover, Figure 5 shows not only the occurrence of each term but also the average impact (citations) of those publications employing each keyword. The most influential keywords are, again, those related to the transnational, gendered and commercial dimensions of surrogacy: reproductive tourism, commodification, CBRC, India, globalization or gender. Hence, we can consider those dimensions to be currently the most influential scopes of current surrogacy research.

If those are the most influential and common topics on surrogacy research, which topics are, on the contrary, being neglected by research? Global surrogacy is an increasingly complex issue that domestic and international policy makers must address. However, only $5.7 \%$ of all publications mention policy in their title, abstract or keywords. Because the inclusion of the term policy does not make a publication policyfocused, the number of policy-focused studies might be even less.

We mentioned before that the international community has expressed mounting concern over the abuses caused by the expansion of global commercial surrogacy, especially exploitation and human trafficking. Notably, only $4.5 \%$ of all documents mention exploitation in a relevant position (title, abstract or keywords). Even more staggering is the fact that just $0.75 \%$ of all surrogacy research considers the issue of human trafficking, and just $0.4 \%$ considers slavery. 


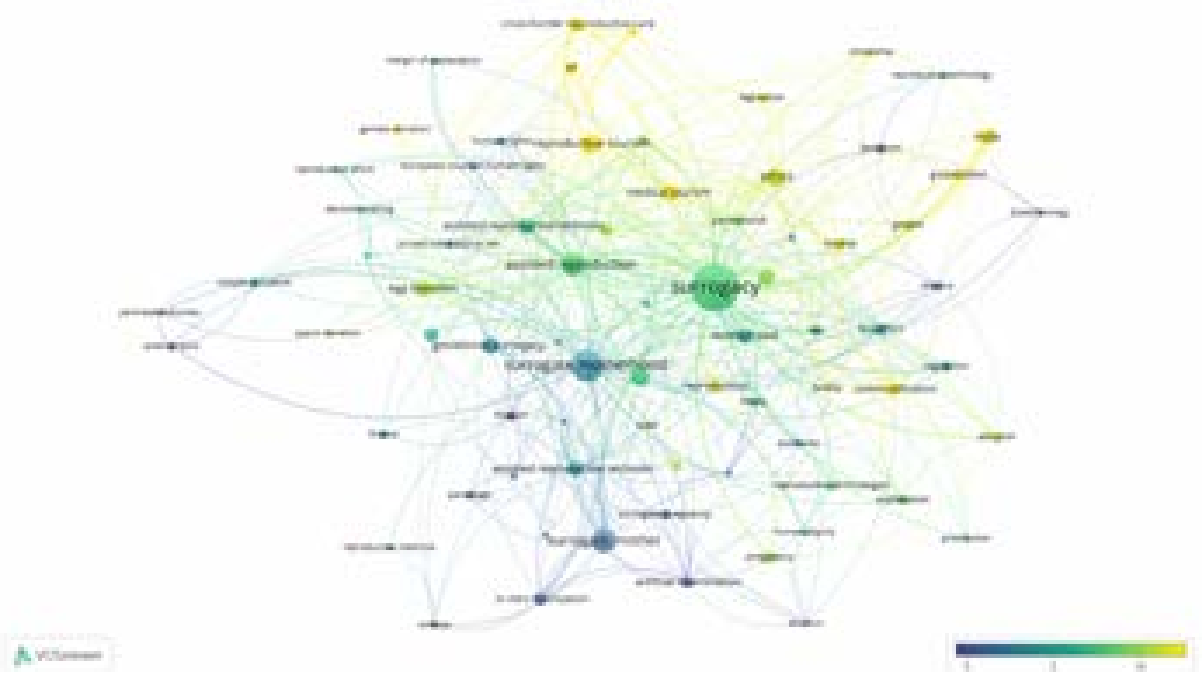

Figure 5. Co-occurrence network of most relevant authors' keywords.

Note: Nodes depict keywords, and their linkages convey co-occurrence relationships. Larger nodes indicate terms with more occurrences. Color shows average citations of those publications using that keyword. Source: own elaboration based on bibliometric analysis

\section{Discussion}

Surrogacy, especially commercial surrogacy, is a highly relevant issue in the fields of health, human rights and ethics. However, academic publications on this topic have not followed a stable trajectory. The spurt of documents exploring the medicolegal and ethical dimensions of surrogate motherhood that followed the Baby $M$ case (1987-88) seemed to exhaust any impetus for research and debate for more than a decade. As it was a judicial case, debate on the issue centered almost exclusively on the ethical and legal issues of domestic surrogacy in the US.

Nevertheless, from 2008-2020, research on the topic grew and adapted to the different concerns arising from the globalization of the practice. As a global fertility industry emerges, researchers are progressively diversifying their perspectives and approaches to surrogacy. After an almost complete focus on the legal aspects of thirdparty reproduction, the current trends show that surrogacy research is increasingly exploring its gendered, racialized and globalized dimensions.

Its transnational nature is being acknowledged by a rising number of studies, which differ in the terminology referring to it. Although medical and reproductive tourism have been some of the most employed terms, there is an emerging consensus questioning the adequacy of these terms. Tourism is usually associated with pleasure and relaxation, so its use may hide the challenges of cross-border surrogacy agree- 
ments (Inhorn \& Patrizio, 2009). For those reasons, cross-border reproductive care (Pennings, Guido et al., 2008) or reproductive exile (Inhorn \& Patrizio, 2009) have been proposed as alternatives. However, the clear connotations of both terms hinder their acceptance. Hence, more neutral terms such as transnational or international surrogacy are the most popular definitions of the phenomenon (Table 3). Currently, although cross-border reproductive care is gaining some traction, transnational or international surrogacy is used in more publications (267) than medical or reproductive tourism (161), cross-border reproductive care (74) and reproductive exile (4).

Its growing multidisciplinarity is a requirement for understanding such a complex phenomenon. Nevertheless, some perspectives are being neglected. Although global surrogacy is an emergent billion-dollar industry and market, economics is not considering it. Less than $5 \%$ of all publications relevantly mention the market nature of surrogacy, while just $2.6 \%$ refer to it as an industry. Overall, publications belonging to the research area of business and economics account for less than $2.5 \%$ of the literature. Moreover, the economic approach to surrogacy has caused a minimal impact: with just 1.6 cites per document (overall average is 4.9), those publications have received only $0.5 \%$ of all cites. Microeconomic rationalization of the decision mechanisms behind surrogacy and adoption, as well as a macroeconomic understanding of this emergent global market, might be useful to better inform policy.

Likewise, the literature is progressively focusing on the transnational nature of surrogacy, yet the internationalist perspective is still lacking. Just $0.2 \%$ of all publications have approached the topic from an international relations and international law perspective. Failure to address the role of and relations between national, international, and transnational actors may lead to the oversimplification of this challenging issue. Similarly, it is striking that there is no extensive development of the impact of new technologies on law and the need for international regulation on the matter.

Table 3. Occurrence (number of publications) of selected terms in titles, abstracts and keywords

\begin{tabular}{|lclc|}
\hline Term & N & Term & N \\
\hline Transnational/international & 267 & Market & 109 \\
\hline Medical/reproductive tourism & 161 & Industry & 59 \\
\hline Cross-border reproductive care & 74 & Exploitation & 102 \\
\hline Reproductive exile & 4 & Trafficking & 17 \\
\hline Policy & 155 & Slavery & 9 \\
\hline
\end{tabular}

Source: Own elaboration 
An additional gap in the literature is policy-oriented research. The lack of policy focus is not an exclusive issue of surrogacy, but it is especially pronounced in this case. While $17 \%$ of all medical tourism literature is policy-oriented (Virani, Wellstead \& Howlett, 2020), this proportion decreases to $6.9 \%$ in the case of surrogacy research. Although research may be policy-relevant when not expressly declared, the dearth of explicit policy-oriented research is a concerning issue. Policy makers, at both the domestic and international levels, need quality research that explicitly addresses the challenges arising from this global phenomenon.

The international community has voiced one of these challenges; global commercial surrogacy may lead to exploitation and even human trafficking. However, these relevant concerns are not being addressed by research. Just $4.5 \%$ of the literature focuses on exploitation, and a staggering $0.7 \%$ focus on trafficking. If surrogacy research continues to neglect these issues, it will leave behind the most vulnerable groups suffering the negative consequences of the global fertility industry. Researchers must address these concerns to identify the dynamics behind them and to better inform policy makers.

Finally, although surrogacy research is quite equally distributed across publication venues and research areas, it is highly geographically concentrated. More than $71 \%$ of citations correspond to documents published in the United States, the United Kingdom and Australia. This imbalance reflects the persistent coloniality of knowledge production. Knowledge coloniality overrepresents some perspectives and obscures others. In the case of surrogacy research, the emergence of the Indian market has received much attention (more than 170 publications). Of these publications on Indian surrogacy, those coming from India received almost 3 times fewer citations on average than those studying India from abroad. As a result, the literature about surrogacy in India often has a clear Eurocentric bias, as Pande has denounced [38]. To counter this imbalance and decolonize research on surrogacy, academic journals and researchers must give voice and credit to local research.

\section{Limitations of the study}

The validity of these results is limited by the usual weaknesses of any bibliometric analysis. The search strategy, although designed to minimize the number of false positives, may include publications not completely focused on the topic. In addition, while the Web of Science is an internationally recognized database offering reliable information, it also has some limitations. In the current study, the main limitation was the exclusion of gray literature from its databases. Nevertheless, this is a common and accepted feature of bibliometric analyses. These limitations need to be considered when studying the findings of the investigation. 


\section{Conclusions}

The current study assessed publication activity on the topic of surrogacy. It has shown that surrogacy is a highly controversial and debated issue that has stimulated more than 2,000 academic publications in recent decades. Two different waves of publications have been identified. The first one followed the Baby $M$ case in 1987-88 and focused on ethical and legal aspects of surrogacy. Since then, research has adapted to the main emerging issues of surrogacy, i.e., its transnational, gendered and human rights dimensions. Surrogacy research is evolving from its focus on law to a growing multidisciplinarity. However, we conclude that there are some aspects that surrogacy research is currently neglecting. Economic assessments of the global market of surrogacy are needed, as well as studies with an international law perspective. In addition, future research should be more policy-oriented and address the main concerns of policy makers and the international community, such as trafficking or exploitation. Finally, to reduce the existing Western bias, research from developing countries should be advanced and, most importantly, listened to.

\section{References}

Andrews, Lori B. (1988). "Surrogate Motherhood: The Challenge for Feminists". Law, Med. and Health Care, 16 (1-2), 72-8o.

BeEson, Diane, Marcy Darnovsky and Abby Lippman (2015). "What's in a name? Variations in terminology of third-party reproduction." Reproductive BioMedicine Online, 31 (6), 805-814.

CAHILl, Lisa Sowle (1988). "The ethics of surrogate motherhood: biology, freedom, and moral obligation". Law, Med. and Health Care, 16 (1-2): 65-71.

Correa da Silva, W. (2021); "The New Brazilian Anti-Trafficking Law: Challenges and Opportunities To Cover The Normative Lack". Revista de Direito Internacional, 18 (1): 242-268.

Dworkin, Andrea (1983). Right-Wing Women. Toronto: General Publishing.

EMAKUnde (2018). ¿Gestación subrogada o vientre de alquiler? Informe final. Donosti: Emakunde.

Farley, Melissa (2018). "Prostitution, Liberalism, and Slavery". Logos, 12 (3): 370-387.

Gonzalez, Juan, Ignacio Garijo y Alfonso Sanchez (2020). "Organ Trafficking and Migration: A Bibliometric Analysis of an Untold Story”. IJERPH, 17 (9): 3204.

Gostin, Lary (1990). Surrogate Motherhood: politics and privacy. Bloomington: Indiana University Press.

Hague Conference on Private International Law (HCCH) (2014). The desirability and feasability of further work on the Parentage. Surrogacy Project. Prel. Doc. 3B. The Hague, Netherlands. 
-. (2015). The Parentage. Surrogacy Project: An updating note. Prel. Doc. 3A. The Hague, Netherlands.

Hatzis, Aristides N. (2003). "Just the oven: a law and economics approach to gestational surrogacy contracts". En Katharina Boele-Woelki (ed.), Perspective for the Unification or Harmonisation of Family Law in Europe. Antwerp: Intersentia.

InHorn, Marcia C. y Pasquale Patrizio (2009). "Rethinking reproductive "tourism" as reproductive exile". Fertility and Sterility, 92 (3): 904-906.

Keтchum, Sara (1989). "Selling Babies and Selling Bodies". Hypatia, 4 (3): 116-127.

LAMM, Eleonora (2013). Gestación por sustitución. Ni maternidad subrogada ni alquiler de vientres. Barcelona: Ed. Universitat Barcelona.

LASker, Shamima Parvin (2018). "Surrogacy around the world". Bangl. J. Bioethics, 8 (3): 1-2.

Macklin, Ruth (1988). "Is There Anything Wrong with Surrogate Motherhood? An Ethical Analysis". Law, Med. and Health Care, 16 (1-2): 57-64.

Matorras, Roberto (2005). “¿Turismo reproductivo o exilio reproductivo?” Revista Iberoamericana de Fertilidad, 22 (2): 85.

Mohapatra, Seema (2012). "Stateless Babies \& Adoption Scams: A Bioethical Analysis of International Commercial Surrogacy”. Berkeley Journal International Law, 30: 412-450.

Palattiyil, George et al. (2010). "Globalization and cross-border reproductive services: Ethical implications of surrogacy in India for social work". International SocialWork, 53 (5): 686-700.

Palattiyil, George et al. (2010). "Globalization and cross-border reproductive services: Ethical implications of surrogacy in India for social work". International SocialWork, 53 (5): 686-700.

PANDE, Amrita (2010). "Commercial surrogacy in India: Manufacturing a perfect mother-worker”. Signs, 35 (4): 969-992.

Pennings, Guido et al. (2008). "ESHRE Task Force on Ethics and Law 15: Crossborder reproductive care". Human Reproducdution, 23 (10): 2182-2184.

Patel, Nayana Hitesh et al. (2018). "Insight into Different Aspects of Surrogacy Practices”. Journal of Human Reproductive, 11 (3): 212-218.

Puleo Garcia, Alicia H. (2017). "Nuevas formas de desigualdad en el mundo globalizado. El alquiler de úteros como extractivismo". Revista Europea de Derechos Fundamentales, 29: 165-184.

Quijano, Anibal (1999). "Colonialidad del poder, cultura y conocimiento en América Latina”. Dispositio, 24 (51): 137-148.

Redondo, Filipa et al. (2017). "Surrogacy: A clash of competing rights". European Judicial Training Network, Brussels.

Rigon, Amalia and Celine Chateau (2016). "Regulating International Surrogacy 
Arrangements - state of Play". Policy Department C: Citizens' Rights and Constitutional Affairs, Brussels: European Parliament.

Robertson, John A. (1988). "Procreative Liberty and the State's Burden of Proof in Regulating Noncoital Reproduction”. Law, Med. And Health Care, 16 (1-2): 18.

Rothman, Barbara Katz (2011). “On Markens”. Sociol. Forum, 26 (1): 201-205.

Steinвоск, Bonnie (1988). "Surrogate Motherhood as Prenatal Adoption". Law, Med. and Health Care, 16(1-2): 44-50.

SweIleH, Waleed M. (2018). "Research trends on human trafficking: A bibliometric analysis using Scopus database". Globalization and Health, 14: 1-12.

Thomson Reuters (2008). Using bibliometrics: A Guide to Evaluating Research Performance with Citation Data. Available at https://bit.ly/3eFqL9M.

United Nations (1989). Convention on the Rights of the Child. Assembly resolution 44/25. United New York: Nations General Assembly.

VAN ECK, Nees Jan and Ludo Waltman (2010). "Software survey: VOSviewer, a computer program for bibliometric mapping." Scientometrics, 84 (2): 523-538.

Virani, Altaf, Adam M. Wellstead and Michael Howlett (2020). "Where is the policy? A bibliometric analysis of the state of policy research on medical tourism". Global Health Research and Policy, 5 (19).

Vitale, Aldo Rocco (2017). "Unified Opposition to Surrogacy: Comparing Feminist and Catholic Views". The National Catholic Bioethics Quarterly, 17 (4): 623-630.

WARNOCK, Mary (1985). Question of Life: The Warnock Report on Human Fertilisation and Embryology. New York: Wiley-Blackwell.

\section{Acknowledgments and funding}

The author thanks Juan González Blanco for his collaboration in carrying out the database and bibliometric analysis. The article has been part of the project results of the research project "Esclavitud contemporánea y trata de personas en el contexto internacional, nacional y andaluz: un estudio jurídico multidisciplinar y transversal” (Ref.: P18-RT-2253), funded by the "Consejería de Economía, Conocimiento, Empresas y Universidad de la Junta de Andalucía", of which the author is part of the research team.

The author also thanks the Andalusian Regional Government's EMERGIA research talent recruitment program.

\section{About the author}

Waldimeiry Correa da Silva is PhD International Law and International Relations, Universidad de Sevilla. Distinguished researcher and lecture in Department International Studies, Department International Public Law and International Relations at Universidad de Sevilla, Spain. Email: wcorrea@us.es. (D) https://orcid. org/0000-0002-1863-8454. 


\title{
REVISTA CHILENA DE DERECHO Y TECNOLOGÍA
}

La Revista Chilena de Derecho y Tecnología es una publicación académica semestral del Centro de Estudios en Derecho Informático de la Facultad de Derecho de la Universidad de Chile, que tiene por objeto difundir en la comunidad jurídica los elementos necesarios para analizar y comprender los alcances y efectos que el desarrollo tecnológico y cultural han producido en la sociedad, especialmente su impacto en la ciencia jurídica.

\author{
EDITOR GENERAL \\ Daniel Álvarez Valenzuela \\ (dalvarez@derecho.uchile.cl) \\ SITIO WEB \\ rchdt.uchile.cl \\ CORREO ELECTRÓNICO \\ rchdt@derecho.uchile.cl \\ LICENCIA DE ESTE ARTÍ́CULO \\ Creative Commons Atribución Compartir Igual 4.o Internacional
}

\begin{abstract}
s
La edición de textos, el diseño editorial

y la conversión a formatos electrónicos de este artículo

estuvieron a cargo de Tipográfica

(www.tipografica.io).
\end{abstract}

